Relations industrielles

Industrial Relations

\title{
Some Reflexions on the Third Convention
}

\section{The Editors}

Volume 3, numéro 8, avril 1948

URI : https://id.erudit.org/iderudit/1023618ar

DOI : https://doi.org/10.7202/1023618ar

Aller au sommaire du numéro

\section{Éditeur(s)}

Département des relations industrielles de l’Université Laval

\section{ISSN}

0034-379X (imprimé)

1703-8138 (numérique)

Découvrir la revue

Citer cet article

The Editors (1948). Some Reflexions on the Third Convention. Relations industrielles / Industrial Relations, 3(8), 128-128.

https://doi.org/10.7202/1023618ar

Tous droits réservés @ Département des relations industrielles de l’Université Laval, 1948
Ce document est protégé par la loi sur le droit d'auteur. L'utilisation des services d'Érudit (y compris la reproduction) est assujettie à sa politique d'utilisation que vous pouvez consulter en ligne.

https://apropos.erudit.org/fr/usagers/politique-dutilisation/ 


\section{SOME REFLEXIONS ON THE THIRD CONVENTION}

The third convention of the Industrial Relations Department ended on a triumphant note. Its full significance became apparant when after the closing dinner, allpresent, moved by the words which the Right Reverend Father Georges-Henri Lévesque had just finished speaking, rose to their feet and experienced in common fellowship an all-pervading loyaltay to the Christian Mysticism of Labour. This address of the Dean of the Faculty of Social Sciences sealed with as much felicity as power, the work of the Convention. It bore witness to the employers as to the employees that all men should respond to the Call of work by which they co-operate in the work of Creation even as they collaborate by their own efforts in the Redemiption of Christ.

In truth, the preceding two days had well prepared the spirit of the delegates for this magnificent conclusion. The choice of theme in the first place was a pressing invitation : «Forms of Employer-Employee co-operation». This pronouncement in itself clearly pointed the way for the exchange of ideas which were to move on to their usual conclusion - Unity.

In the second place the very character of the Convention favoured such conditions. It is always difficult in a negotiation aiming at a collective agreement to find sufficient freedom of spirit so that the meetings between employers and workers result in general ideas being brought forward and discussed. It is the objective character of the exchanges of opinion taking place which gives to our Conventions their particular fruitfulness. All parties present can expound their point of view in complete sincerity and without having to reach an immediate practical decision. Each one of the parties thus demonstrates that it has the courage to comprehend thoroughly what the other party thinks. And from this meeting can come a mutual knowledge which, if it is not yet collaboration is one of its pre-requisite conditions. If meeting is not enough to produce understanding there is one sure way to avoid understanding - and that is not to meet at all. In gathering to the number of more than four hundred for the Laval Convention of Industrial Relations, employers and workers of the Province of Québec have shown their will to understand better than by all their speeches.

In the third place the questions considered in each of the sessions also favoured the manifestation of unity to which the banquet paid tribute. Employer-employee co-operation for apprenticeship, for industrial hygiene, for joint-production committees, for collective bargaining - these four subjects covered fully all the essential problems - the training of the worker, his psycho-physiological equilibrium, the meeting on the scale of the enterprise, the meeting on the scale of the profession.

This year's discussions will be fully reproduced in the report shortly to be published. We shall not dwell at length on them but, in closing, we would emphasize the great success of the separate meetings held on the evening of the first day. Divided into four groups according to their professional classification, the delegates found that this way of grouping rounded out happily the general meetings. There they chose themselves the subjects for discussion which again facilitated the freedom and the fruitfulness of this annual encounter.

In closing, we wish to express to all who came our sincere gratitude. Their sustained attention, the seriousness and the scope of the discussions greatly impressed certain of those who joined with us for the first time. Our thanks to all.

Here's to next year !

The Editors 